Журнал«Герспективитаінноваціїнаукиљ

(Серія «Гедагогіка», Серія«ГТихологія», Серія«Медицина»

№2(7) 2022

УДК 159.9.01

https://doi.org/10.52058/2786-4952-2022-2(7)-934-942

Помиткіна Любов Віталіївна доктор психологічних наук, професор, завідувач кафедри авіаційної психології, Національний авіаційний університет, проспект Любомира Гузара, 1, м. Київ, 03058, тел.: (099) 138-4738, https://orcid.org/0000-0002-2148-9728

Ковтун Олена Віталіївна доктор педагогічних наук, професор, завідувач кафедри іноземної філології, Національний авіаційний університет, проспект Любомира Гузара, 1, м. Київ, 03058, тел.: (067) 7539892, https://orcid.org/0000-0001-5216-6350

Ладогубець Наталія Віталіївна кандидат педагогічних наук, доцент, декан факультету лінгвістики та соціальних комунікацій, Національний авіаційний університет, проспект Любомира Гузара, 1, м. Київ, 03058, тел.: (098) 385-8729, https://orcid.org/0000-0003-4321-3201

\title{
ТРАНСФОРМАЦІЯ ОСВІТИ В ПОСТПАНДЕМІЧНИЙ ПЕРІОД: АНАЛІТИЧНИЙ ОГЛЯД
}

Анотація. Прогнозування стану освіти в Україні в постпандемічний період $\epsilon$ надзвичайно актуальною проблемою суспільства, оскільки навчання й виховання підростаючого покоління завжди було в пріоритеті кожної держави. В умовах, що склалися в освіті України у зв'язку з світовою пандемією COVID19 відбуваються зміни, які потребують усвідомлення й розуміння необхідності внесення кардинальних перетворень.

Метою статті було висвітлення результатів аналітичного огляду проблеми трансформації освіти в постпандемічний період. Аналізуючи праці вітчизняних колег, визначено занепокоєння вчених 3 приводу розгортання неадекватних тенденцій у навчально-виховному процесі середньої та вищої школи. Аналітичний огляд трансформації освіти в постпандемічний період дозволив виділити два напрями розгортання проблеми: позитивний - зростання швидкості опанування новостворених гаджетів, платформ (Classroom, Meet, Zoom, Test UNIT, TeamSetupx та багато ін.), опанування віртуальною реальністю; негативний - зниження якості реалізації освітньо-навчальних послуг, зростання психоемоційної напруженості як для студентів так i для викладачів; збільшення сварок у сім'ї, зростання незадоволеності й роздратування у батьків ситуацією, що створена, в цілому - порушення гармонійного сімейного простору. Дослідження дозволило узагальнити групи негативних наслідків, відповідно до споживачів освіти та учасників навчально-виховного процесу: для студентів і школярів, для викладачів і вчителів, для батьків. 
У висновку наголошено: 3 метою протистояння негативним психологічним наслідкам дистанційного навчання, зумовленого короновірусною пандемією, необхідно розробляти новітні підходи й методи психолого-педагогічного супроводу процесу навчання в загальноосвітніх навчальних закладах та ВН3 нашої держави.

Ключові слова: освіта, навчання, короновірусна пандемія, учасники навчально-виховного процесу, трансформація освіти.

Pomytkina Liubov Vitaliyivna Doctor of Psychological Sciences, Professor, Head of the Department of Aviation Psychology, National Aviation University, 1 Lyubomyr Husar Ave., Kyiv, 03058, tel.: (099) 138-4738, https://orcid.org/0000-0002-2148-9728

Kovtun Olena Vitaliyivna Doctor of Pedagogical Sciences, Professor, Head of the Department of Foreign Philology, National Aviation University, 1 Lyubomyr Husar Ave., Kyiv, 03058, tel.: (067) 7539892, https://orcid.org/0000-0001-5216-6350

Ladohubets Nataliia Vitaliyivna $\mathrm{PhD}$ of Pedagogical Sciences, Associate Professor, Dean of the Linguistics and Social Communications Faculty, National Aviation University, 1 Lyubomyr Husar Ave., Kyiv, 03058, tel.: (098) 385-8729, https://orcid.org/0000-0003-4321-3201

\title{
TRANSFORMATION OF EDUCATION IN THE POST-PANDEMIC PERIOD: ANALYTICAL REVIEW
}

\begin{abstract}
Forecasting the state of education in Ukraine in the post-pandemic period is an extremely important problem of society, as education and upbringing of the younger generation has always been a priority of every state. In the current conditions in the education of Ukraine due to the global COVID-19 pandemic, the changes that require awareness and understanding of the need for radical transformations are taking place.

The aim of the article was to highlight the results of the analytical review of the problem of transformation of education in the post-pandemic period. Analyzing the work of domestic colleagues, the concerns of scientists about the development of inadequate trends in the educational process of secondary and higher education were identified. Analytical review of the transformation of education in the post-pandemic period revealed two areas of issue deployment: positive - increasing the speed of mastering newly created gadgets, platforms (Classroom, Meet, Zoom, Test UNIT, TeamSetupx, etc.), mastering virtual reality; negative - reducing the quality of educational services, increasing psycho-emotional tension for both students and teachers; increasing quarrels in the family, growing dissatisfaction and irritation of parents with the situation created, in general - a violation of a harmonious family space. The study allowed to generalize the groups of negative consequences,
\end{abstract}


according to consumers of education and participants in the educational process: for students and schoolchildren, for teachers, for parents.

The conclusion emphasizes that in order to counteract the negative psychological consequences of distance learning caused by the coronavirus pandemic, it is necessary to develop new approaches and methods of psychological and pedagogical support of the learning process in secondary schools and higher educational institutions of our country.

Keywords: education, training, coronavirus pandemic, participants of educational process, transformation of education.

Постановка проблеми. В умовах, що склалися в освіті України у зв'язку з світовою пандемією COVID-19 відбуваються зміни, які потребують усвідомлення й розуміння необхідності внесення кардинальних змін. Вже три роки продовжується пандемія, і вже три роки школярі та студенти знаходяться на дистанційному навчанні - навчаються в онлайн. Ця обставина не могла не принести певні наслідки, про які буде висвітлено у статті.

Проблеми, що склалися в освіті аналізують вчені в різних галузях економісти, педагоги, психологи, соціологи, філософи та ін. Акцентування уваги провідних вчених на проблему потребує уваги всіх учасників навчальновиховного процесу закладів середньої та вищої освіти. Проблему з різних боків висвітлюють Дмитренко Г.А., Головач Н.В., Залат-Лозинська Л.О., Помиткін Е.О., Іванова О.В., Рибалка В.В., Хохліна О.П. та багато інших. Аналіз результатів досліджень вчених вказує на нагальну потребу в перегляді форм і методів роботи в навчальній діяльності.

Метою статті $\epsilon$ висвітлення результатів аналітичного огляду проблеми трансформації освіти в постпандемічний період.

Сучасний глобалізований світ сповнений протиріч, однак освіта взагалі й навчання, зокрема, завжди були орієнтовані на високий рівень свідомості громадян, розвинену аналітико-пізнавальну активність, масштабне мислення, а також на загальнолюдські гуманістичні позитивні цінності. Впродовж останніх років відбувається розмитість ідеалів, смислів, цінностей, зниження прагнення до духовного зростання як на державному рівні так і серед пересічних громадян та серед здобувачів освіти.

Аналіз останніх досліджень і публікацій. Аналізуючи праці вітчизняних колег, знаходимо глибокий аналіз та занепокоєння 3 приводу розгортання неадекватних тенденцій в навчально-виховному процесі середньої та вищої школи. Так, вчені Дмитренко Г.А., Головач Н.В., Залат-Лозинська Л.О. вказують, що сучасний стан освітньої галузі в Україні просто «жахливий», i це одна з причин, за якої випускники шкіл шукають все частіше продовження освіти за кордоном [1].

Виклад основного матеріалу. Розгортання ковідної ситуації трохи знизило міграцію української молоді на навчання за кордон, однак віддаючи належне інформативності 3MI i мережам Інтернет, сучасні абітуріснти достатньо ознайомлені з перевагами життя й навчання в зарубіжних країнах. 
Зміст сучасної монографії колективу авторів на чолі 3 професором Рибалкою В.В. спрямований на покращення самопочуття та підтримання психологічної стабільності сучасного суспільства в умовах глобальної дестабілізації соціально-економічної ситуації, викликаної пандемією COVID-19. Вчені зазначають, що спільна психологічна неготовність до появи нової реальності, зростання тривоги громадян, коли вони сприймають постійно зростаючий потік інформації в контексті динамічної реструктуризації звичного способу життя, викликають необхідність проведення спеціальних філософських, психологічних і педагогічних заходів з різними категоріями населення [8].

На засадах особистісно-орієнтованого підходу розроблена психологічна профілактика і гігієна особистості у протидії пандемії COVID-19 колективу Інституту педагогічної освіти і освіти дорослих імені Івана Зязюна НАПН України. Дослідження науковців презентують концептуальні та практичні питання психологічної профілактики і гігієни особистості у протидії пандемії, що охопила весь світ і Україну. Наводяться дані щодо наукового розуміння пандемії, стратегії і тактики надання психологічної допомоги населенню, психогігієнічних засад формування нового способу життя в умовах антивірусного карантину, поради і правила саногенної поведінки особистості у зоні пандемії, етичні засади раціогуманізму у протидії пандемічній загрозі [3].

Видатний філософ і педагог Зязюн I.А. у своїй праці «Педагогіка Добра» визначав основоположні правила здорв’язбереження і щастя нації - Красу, Добро та Істину, які пропагував усе життя, намагаючись донести їх до кожного студента педагогічної галузі. Досліджуючи проблеми та перспективи формування національної гуманітарно-технічної еліти, вчений вважав, що на найвищому щаблі управління державою має стояти духовна еліта, основними проявами якої у суспільстві мають бути інтелігентність і громадянськість [2].

У працях Помиткіна Е.О. актуалізується проблема розробки психологопедагогічного супроводу духовно-культурного виховання особистості у XXI столітті. Вчений презентував психологічну модель особистості з високим духовним потенціалом як орієнтир виховного процесу, яка містить 125 позитивних якостей, необхідних для самореалізації особистості. Автор пропонує психолого-педагогічні засоби, спрямовані на духовно-культурне виховання особистості на різних вікових етапах, які мають грунтуватися на природних потребах i закономірностях духовного розвитку особистості, враховувати фактори, що впливають на духовне становлення дітей і молоді [4].

Колектив авторів на чолі 3 Хохліною О.П. висвітлили результати теоретичного та емпіричного дослідження проблеми стильових детермінант спілкування сучасних студентів [6]. Стильові особливості життєдіяльності людини, а саме стилі спілкування студентської молоді авіаційної галузі, як специфічна форма людської діяльності полягають у взаємодії партнерів, суб'єктсуб'єктних відносинах. Стиль життєвої діяльності розглядається як спосіб існування особи, що характеризується оригінальністю; він охоплює всю систему буття людини, його внутрішні i зовнішні прояви, i забезпечує активність 
визначеності в характеристика та передбачуваність поведінки в широкому діапазоні ситуацій. У статті відображено теоретичні основи проведеного дослідження та отримані емпіричні дані про студентів, їх стилі спілкування та їх зв'язок з психічними якостями особистості.

Виявлено, що сучасна студентська молодь характеризується використанням у спілкуванні широкого діапазону засобів, серед яких, за різними класифікаціями, переважають такі стилі, як: альтруїстичний, кооперативні, колегіальні, ліберальні, діалогічні, компромісні, які за своїм змістом свідчать про орієнтацію суб'єкта на партнера, співпрацю 3 ним, пошук спільного рішення, взаємну повагу тощо, демонструючи здатність до спілкування.

Однак, враховуючи обставини світової пандемії та дистанційне навчання в онлайн, отримані дані вказують на потребу студентів у розширенні арсеналу засобів комунікації та використанні здібностей до вимог життєдіяльності.

Дослідники Помиткін Е.О, Іванова О.В. у власних працях висвітлили результати дослідження емоційних станів вчителів Нової української школи в період пандемії COVID-19. Вони констатували проблему ускладнення виконання професійних обов'язків через недостатню компетентність у використанні IKT і нестабільний психологічний стан, який виявляється у негативних емоційних переживаннях. У результаті ряду досліджень виявлено, що грунтовні емоційні станів вчителів НУШ під час пандемії коронавірусної інфекції погіршуються.

Встановлено, що переважна кількість перебуває у станах, близьких до фрустрації - сумнів, смуток, розгубленість. Проаналізовано причини цих деструктивних станів, які пов'язані, зокрема, з відсутністю необхідних навичок для здійснення дистанційного навчання, а також через високі вимоги з боку держави і батьків до особистості вчителя НУШ. Результати дослідження підтвердили потребу в наданні психологічної допомоги вчителям, особливо старшим 45 років [7].

Говорячи про вчителів та викладачів, майже $62 \%$ iз них вказують, що працювати в онлайн складніше. По-перше, не всі студенти заходячи в класруми відкривають свої обличчя! Замість цього виставляють різні «аватарки», i на вимогу викладача відкритися, знаходять безліч причин, щоб цього не робити. У результаті викладач наче спілкується сам із собою, що знижує емоційне забарвлення, обмежує дидактику, ейфорію подання класного й корисного матеріалу, в цілому - забирає енергію, оскільки не відбувається обмін взаємодії аудиторії студент-викладач.

По-друге, викладач весь час думає про те, чи дійсно студент його слухає, чи займається сторонніми справами, чи взагалі відсутній, що перебиває ефективність викладу підготовленого матеріалу. Тобто цілісність когнітивностильових функцій спілкування аудиторії порушується.

По-третє, зростає навантаження на викладача: 1) збільшення часу на необхідність підготовки відеопрезентацій, щоб і зацікавити студента і задіяти 
сприймання матеріалу не лише слуховими аналізаторами, а й візуальними; 2) збільшення часу на створення завдань, їх перевірку, виставлення оцінок, призначення окремих індивідуальних завдань, опрацювання усіх необхідних матеріалів тощо.

Аналітичний огляд трансформації освіти в постпандемічний період дозволяє виділити два напрями розгортання проблеми:

1) позитивний - зростання швидкості опанування новостворених гаджетів, платформ (Classroom, Meet, Zoom, Test UNIT, TeamSetupx та багато ін.), опанування віртуальною реальністю.

2) негативний - зниження якості реалізації освітньо-навчальних послуг, зростання психоемоційної напруженості як для студентів так i для викладачів; збільшення сварок у сім’ї, зростання незадоволеності й роздратування у батьків ситуацією, що створена, в цілому - порушення гармонійного сімейного простору.

Надалі вважаємо за необхідне узагальнити групи наслідків, відповідно до споживачів освіти та учасників навчально-виховного процесу.

Наслідки для студентів та школярів:

1) порушення режиму дня зі зниженням імунітету та зниженням адаптивних ресурсів фізичного здоров'я;

2) втрата відкритого спілкування 3 викладачами зі зниженням мотивації до навчання та самонавчання;

3) зменшення відвідування кількості занять в онлайн зі збільшенням закритості та розвитком ознак самотності;

4) втрата зустрічей із друзями та референтним оточенням зі зниженням комунікативних навичок соціального спілкування і поведінки;

5) втрата мотивації до професійного зростання, самоудосконалення, саморозвитку та до прагнення до успіху;

6) зростання ознак інтравертованості, застрягання, самотності та аутичності;

7) втрата відчуття щастя!

Наслідки для викладачів та вчителів:

1) поява негативних емоційних переживань;

2) поява деструктивних станів, близьких до фрустрації - сумнів, смуток, розгубленість, які пов'язані, зокрема, з відсутністю необхідних навичок для здійснення дистанційного навчання, а також через високі вимоги з боку держави і батьків до особистості вчителя, викладача;

3) зниження мотивації до успіху, до самореалізації та професійного зростання;

4) втрата задоволеності професійною діяльністю;

5) втрата відчуття щастя!

Наслідки для батьків:

1) зростання незадоволеності власними дітьми;

2) порушення сімейних ролей; 
3) зростання психоемоційної напруженості, роздратованості й безпорадності;

4) втрата довірливих стосунків у сім'ї;

5) «втеча у професійну діяльність» батьків від відповідальності за навчання й виховання власних дітей;

6) порушення гармонії у сім’ї;

7) втрата відчуття щастя!

Отже, говорячи про трансформацію освіти й про їі майбутне, необхідно вибудовувати нові підходи до управління освітою та до методів психологопедагогічного супроводу усіх учасників навчально-виховного процесу. Зокрема, такими можуть бути:

оновлення навчальних програм, що надасть можливість знайти місце для тих предметів і тем, які життєво необхідні дітям і молоді. Серед них психологія самопізнання та самовдосконалення, толерантне спілкування, підготовка до вибору шлюбного партнера та успішної побудови сімейних стосунків, правильне виховання дітей, вибір професії та шляхів мирної самореалізації у динамічному світі;

виховання екологічної свідомості, що зробить світ чистішим i підвищить рівень відповідальності за власний дім, школу чи ВУЗ, країну, планету;

- усвідомлення необхідності слідування правилам здорового способу життя, що підвищить імунітет організму і забезпечить здатність до протистояння будь-яким інфекціям.

Висновки. Аналітичний огляд результатів досліджень проблеми трансформації освіти в постковідний період показав: сучасну освіту слід звільнити від переобтяження інформацією, яку людина не в змозі осмислити та використати протягом свого життя, від застарілих форм і методів навчання. В основу освітньої парадигми мають бути покладені не лише знання, а й цінності, смисли людського існування і коли це буде реалізовано, людство зможе зробити суттєвий крок від епохи інформатизації до епохи культури та духовності в постковідний період. 3 метою протистояння негативним психологічним наслідкам дистанційного навчання, зумовленого короновірусною пандемією, необхідно розробляти новітні підходи й методи психолого-педагогічного супроводу процесу навчання в загальноосвітніх навчальних закладах та ВНЗ нашої держави.

\section{Лimepamypa:}

1. Дмитренко Г.А., Головач Н.В., Залат-Лозинська Л.О. Стратегія розвитку людства. Новий гуманізм в освіті / за заг. ред. Г.А.Дмитренка. К.: ДКС-Центр, 2021. 258 с.

2. Зязюн I. А. Духовна еліта у суспільстві: інтелігентність і громадянськість / Іван Зязюн // Проблеми та перспективи формування національної гуманітарно-технічної еліти: зб. наук. пр.: [у 2-х ч.] / за ред. Л. Л. Товажнянського, О. Г. Романовського; НТУ «ХПІ». Х., 2003. Ч. 1(5). С. 32-42.

3. Психологічна профілактика і гігієна особистості у протидії пандемії COVID-19: Методичний посібник / Авт. кол.: Рибалка В.В. та ін. - Київ: Інститут педагогічної освіти і освіти дорослих імені Івана Зязюна НАПН України, 12-29 березня 2020. 123 с. 
4. Помиткіна Л.В., Помиткін Е.О. Психолого-педагогічний супровід духовнокультурного виховання особистості у XXI столітті / Духовність особистості: методологія, теорія і практика : зб. наук. пр. / За мат-ми X Міжн. наук.-пр. конф. «Духовно-культурне виховання особистості в умовах входження людства в Епоху Культури» в рамках міжн-го проекту Д. Пола Шафера «Епоха Культури» (30 травня 2019 року, м. Київ); Ч. І. / Гол. редактор Г. П. Шевченко. Вип. 2 (89). Сєвєродонецьк: вид-во СНУ ім. В. Даля, 2019. С.153-167.

5. Помиткіна Л.В., Помиткін Е.О. Миротворча роль освіти у XXI столітті / VIII Українсько-Польський / Польсько-український науковий форум / Освіта для миру = Edukacja dla pokoju: зб. наук. пр.: у 2 т. / редкол.: Кремень В.Г. (голова); Коцур В.П., Ничкало Н.Г., Шльосек Ф. (заст. голови); Довгий С.О., Лукянова Л.Б., Вовк М.П., Котун К.В. (члени редколегіï). К.: Вид-во ТОВ «Юрка Любченка», 2019. Т.1. С.264-274.

6. L. Pomytkina, O. Khokhlina, O. Lych, S. Gorbenko, A. Kazak. Psychological determinacy of communication styles of aviation industry students / IOP Conf. Series: Materials Science and Engineering 918 (2020) 012175 IOP Publishing

doi: https://iopscience.iop.org/article/10.1088/1757-899X/918/1/012175/pdf

7. Pomytkin, E. O., Pomytkina, L. V., \& Ivanova, O. V. (2020). Electronic resources for studying the emotional states of new Ukrainian school teachers during the Covid-19 pandemic. Information Technologies and Learning Tools, 80(6), 267-280. https://doi.org/10.33407/itlt.v80i6.4179

8. Pomytkin E. O., Pomytkina L.V. (2020). Strategy and Tactics of Conscious Psychological Counteraction of Humanity to Viral Diseases / Philosophy, psychology and pedagogics against COVID-19: Manual / Ed. : V. V. Rybalka, A. P. Samodryn, O. V.Voznyuk and others; a team of authors. Zhytomyr: Publisher O. Yevenok, p.119-133.

\section{References:}

1. Dmytrenko H.A., Holovach N.V., \& Zalat-Lozynska L.O. (2021). Stratehiia rozvytku liudstva. Novyi humanizm v osviti [The Human development strategy. New humanism in education] / za zah. red. H.A.Dmytrenka. K.: DKS-Tsentr [in Ukrainian].

2. Ziaziun I. A. (2003). Dukhovna elita u suspilstvi: intelihentnist i hromadianskist [Spiritual elite in society: intelligence and citizenship] / Ivan Ziaziun // Problemy ta perspektyvy formuvannia natsionalnoi humanitarno-tekhnichnoi elity: zb. nauk. pr.: [u 2-kh ch.] / za red. L. L. Tovazhnianskoho, O. H. Romanovskoho; NTU «KhPI». X. Ch. 1(5). 32-42 [in Ukrainian].

3. Rybalka V.V. (Eds.). Psykholohichna profilaktyka $i$ hihiiena osobystosti u protydii pandemii COVID-19: Metodychnyi posibnyk [Psychological prevention and hygiene of the individual in response to the pandemic TsOVID-19] / Avt. kol.: Rybalka V.V. ta in. - Kyiv: Instytut pedahohichnoi osvity i osvity doroslykh imeni Ivana Ziaziuna NAPN Ukrainy, 2020 [in Ukrainian].

4. Pomytkina L.V., \& Pomytkin E.O. (2019a). Psykholoho-pedahohichnyi suprovid dukhovno-kulturnoho vykhovannia osobystosti u XXI stolitti [Psychological and pedagogical support of spiritual and cultural education of the individual in the XXI century] / Dukhovnist osobystosti: metodolohiia, teoriia i praktyka : zb. nauk. pr. / Za mat-my X Mizhn. nauk.-pr. konf. «Dukhovno-kulturne vykhovannia osobystosti v umovakh vkhodzhennia liudstva v Epokhu Kultury» v ramkakh mizhn-ho proektu D. Pola Shafera «Epokha Kultury» (30 travnia 2019 roku, m. Kyiv); Ch. I. / Hol. redaktor H. P. Shevchenko. Vyp. 2 (89). Sievierodonetsk: vyd-vo SNU im. V. Dalia. 153-167 [in Ukrainian].

5. Pomytkina L.V., \& Pomytkin E.O. (2019b). Myrotvorcha rol osvity u XXI stolitti [The peacekeeping role of education in the XXI century] / VIII Ukrainsko-Polskyi / Polsko-ukrainskyi naukovyi forum / Osvita dlia myru = Edukacja dla pokoju: zb. nauk. pr.: u 2 t. / redkol.: Kremen V.H. (holova); Kotsur V.P., Nychkalo N.H., Shlosek F. (zast. holovy); Dovhyi S.O., Lukianova L.B., Vovk M.P., Kotun K.V. (chleny redkolehii). K.: Vyd-vo TOV «Iurka Liubchenka». T.1. 264-274 [in Ukrainian]. 
6. L. Pomytkina, O. Khokhlina, O. Lych, S. Gorbenko, \& A. Kazak. (2020). Psychological determinacy of communication styles of aviation industry students / IOP Conf. Series: Materials Science and Engineering 918012175 IOP Publishing [in Russia].

doi: https://iopscience.iop.org/article/10.1088/1757-899X/918/1/012175/pdf

7. Pomytkin, E. O., Pomytkina, L. V., \& Ivanova, O. V. (2020). Electronic resources for studying the emotional states of new Ukrainian school teachers during the Covid-19 pandemic. Information Technologies and Learning Tools, 80(6), 267-280 [in Ukrainian]. https://doi.org/10.33407/itlt.v80i6.4179

8. Pomytkin E. O., \& Pomytkina L.V. (2020). Strategy and Tactics of Conscious Psychological Counteraction of Humanity to Viral Diseases / Philosophy, psychology and pedagogics against COVID-19: Manual / Ed. : V. V. Rybalka, A. P. Samodryn, O. V.Voznyuk and others; a team of authors. Zhytomyr: Publisher O. Yevenok. 119-133 [in Ukrainian].

Стаття підготовлена в рамках проєкту «Вища освіта в період постпандемії: трансформації, виклики та перспективи» за сприяння МОН (Наказ МОН № 1461 від 29.12.21р.). 